\title{
Karakteristik Ibu Hamil yang tidak Melakukan Kunjungan Ulang Pemeriksaan Kehamilan Keempat(K4)
}

\author{
Characteristics of Pregnant Women Not Conducting \\ Fourth Ante Natal Care
}

\author{
Ranny Septiani $\mathbf{1}^{1, \bigotimes}$ \\ ${ }^{1}$ Jurusan Kebidanan, Politeknik Kesehatan Tanjung Karang, Indonesia \\ ${ }^{\circledR}$ Coresponding author: koeny.rani@gmail.com
}

\begin{abstract}
Kata kunci:
Karakteristik ibu

hamil,

Pemeriksaan

kehamilan,

Kunjungan ulang

kehamilan keempat

(K4).

Abstrak

Latar belakang: Indikator yang digunakan untuk menggambarkan ketidakberhasilan program pelayanan kesehatan ibu adalah cakupan pemeriksaan ibu hamil terhadap pelayanan kesehatan yang diukur dengan kunjungan kehamilan pertama (K1) dan kunjungan kehamilan keempat (K4). Tujuan: Penelitian ini bertujuan untuk mengetahui gambaran karakteristik ibu hamil yang tidak melakukan kunjungan ulang pemeriksaan kehamilan keempat (K4) di Puskesmas Bungin Kabupaten Lampung Barat. Metode: Penelitian ini merupakan penelitian deskriptif dengan pendekatan cross sectional. Sampel penelitian adalah ibu hamil di Puskesmas Bungin Kabupaten Lampung Barat yang berjumlah 152 orang yang diambil menggunakan teknik simple random sampling. Varibel yang diteliti, yaitu usia, pendidikan, pekerjaan, paritas dan jarak rumah tinggal ke fasilitas kesehatan.Pengumpulan data bersumber dari kohort ibu hamil yangdianalisis secara univariat untuk melihat proporsi ibu yang tidak melakukan K4. Hasil: Ibu hamil yang tidak melakukan kunjungan ulang keempat (K4) dengan variabel terbanyak usia berisiko tinggi $67 \%$ orang, pendidikan rendah $48 \%$ orang, tidak bekerja $70 \%$ orang, primipara dan multipara sama-sama berjumlah $42 \%$ orang, serta mempunyai jarak rumah tinggal yang dekat dengan fasilitas kesehatan $67,1 \%$ orang. Simpulan: Kecenderungan ibu hamil tidak melakukan kunjungan kehamilan keempat dengan karakteristik usia berisiko tinggi, pendidikan rendah, tidak bekerja, primipara dan multipara.
\end{abstract}

\section{Keyword:}

Characteristic of pregnant mother,

Pregnancy

examination,

Fourthante natal care.

\begin{abstract}
Background:Background. The indicator used to describe the failure of the maternal health service program is the coverage of the examination of pregnant women on health services as measured by the first pregnancy visit and the fourth pregnancy visit. Purpose: This study purposes to describe the characteristics of pregnant women who did not re-visit the fourth pregnancy checkup at the Bungin Health Center in West Lampung Regency. Method: This study is a descriptive study with a cross sectional approach. The research sample was 152 pregnant women taken using simple random sampling technique. The variables studied were age, education, employment, parity and distance of home to health facilities. Data collection was sourced from cohorts of pregnant women who were analyzed univariately to see the proportion of mothers who did not do fourth repeat visit. Result: Pregnant women who did not make a fourth repeat visit with the highest characteristics were at high risk of $67 \%$, low education was $48 \%$, not working $70 \%$ of people, primiparous and multiparous were $42 \%$, and had a distance from home living near health facilities $67.1 \%$ of people. Conclusion: The tendency of pregnant women not to make a fourth pregnancy visit with characteristics of high-risk age, low education, unemployment, primiparas and multiparas.
\end{abstract}

Copyright $@ 2018$ Jurnal Kesehatan Metro Sai Wawai. All rights reserved. 


\section{Pendahuluan}

Tingginya angka kematian ibu dapat menunjukkan masih rendahnya kualitas pelayanan kesehatan. Penurunan AKI juga merupakan indikator keberhasilan derajat kesehatan suatu wilayah. Pemerintah berupaya untuk melakukan berbagai program dengan tujuan menurunkan AKI.Program Kesehatan Ibu dan Anak merupakan salah satu prioritas Kementerian Kesehatan dan keberhasilan program KIA menjadi salah satu indikator utama dalam Rencana Pembangunan Jangka Panjang Nasional (RPJPN) 2005 - 2025. Tingginya Angka Kematian Ibu (AKI) di Indonesia membuat pemerintah menempatkan upaya penurunan AKI sebagai program prioritas dalam pembangunan kesehatan (Depkes RI, 2004).

Masalah kematian dan kesakitan ibu di Indonesia masih merupakan masalah besar. Angka Kematian Ibu (AKI) menurut SDKI (Survey Demografi Kesehatan Indonesia) Tahun 2012, di Indonesia mencapai angka per 100.000 kelahiran hidup dan Angka Kematian Bayi (AKB) sebesar per 1.000 kelahiran hidup. Jumlah AKI dan AKB masih jauh dari target Millenium Development Goals (MDGs) 2015 yaitu AKI sebesar 102 per 100.000 kelahiran hidup dan AKB sebesar 23 per 100.000 kelahiran hidup, sehingga masih memerlukan kerja keras dari semua komponen untuk mencapai target tersebut (Departemen Kesehatan RI, 2008).

Kematian ibu di provinsi Lampung cenderung terjadi peningkatan. Pada tahun 2012 di Provinsi Lampung terjadi 178 kasus kematian ibu dan meningkat menjadi 359 kasus kematian ibu pada tahun 2013, sedangkan kasus kematian ibu di Kabupaten Lampung Barat tahun 2013 sebanyak 16 orang. Penyebab langsung kematian ibu adalah perdarahan, infeksi, toxemia gravidarum, partus macet (persalinan kasep), abortus dan ruptur uteri (Dinkes Lampung Barat , 2013). Gambaran tersebut menunjukkan bahwa penyebab-penyebab langsung kematian ibu sebagian besar dapat dideteksi dan dicegah pada masa kehamilan yaitu dengan pelaksanaan asuhan kebidanan atau biasa dikenal Antenatal Care (ANC). Untuk meningkatkan keselamatan ibu dan bayi baru lahir, asuhan antenatal harus lebih difokuskan pada intervensi yang telah terbukti bermanfaat menurunkan angka kesakitan dan kematian ibu dan bayi baru lahir (Depkes RI, 2006).

Indikator yang digunakan untuk menggambarkan keberhasilan program pelayanan kesehatan ibu adalah cakupan pemeriksaan ibu hamil terhadap pelayanan kesehatan yang diukur dengan K1 dan K4. Cakupan K1 merupakan gambaran besaran ibu hamil yang telah melakukan kunjungan pertama ke fasilitas pelayanan kesehatan untuk mendapatkan pelayanan antenatal. K4 kontak ibu hamil dengan tenaga kesehatan yang keempat (atau lebih) untuk mendapatkan pelayanan antenatal sesuai standar yang ditetapkan, dengan ketentuan satu kali pada triwulan pertama, satu kali pada triwulan kedua, dan dua kali pada triwulan ketiga (Departemen Kesehatan RI, 2008).

Pemanfaatan pelayanan ANC oleh seorang ibu hamil dapat dilihat dari cakupan pelayanan ANC (K1 dan K4). Cakupan K1 Puskesmas Bungin Tahun 2013 berjumlah 93\%, sedangkan cakupan K4 menurun, yaitu $78 \%$ dari 338 ibu hamil. Pada data 2014 cakupan K1 dan K4 lebih menurun dibandingkan tahun 2013. Cakupan K1 tahun 2014 berjumlah 97\%, sementara cakupan K4 hanya 71\% dari 346 ibu hamil. Cakupan K4 tersebut jauh dibawah target nasional (90\%) (Puskesmas Bungin Kabupaten Lampung Barat, 2014).

Kunjungan pemeriksaan kehamilan (K4) merupakan salah satu bentuk perilaku. Suatu perilaku akan dipengaruhi oleh berbagai faktor, salah satunya faktor karakteristik yaitu karakteristik lingkungan yang terdiri dari budaya, kelas sosial, keluarga dan situasi sedamgkan karakteristik yang kedua adalah karakteristik individu yang terdiri dari demografi (umur, jenis kelamin, suku agama, status perkawinan, jumlah anak, pendidikan, pekerjaan dan pendapatan) dan lain-lain (Notoatmodjo, 2005). Penelitian ini bertujuan mengidentifikasi karakteritik ibu hamil tidak melakukan kunjungan ulang pemeriksaan kehamilan keempat (K4) di Wilayah Kerja Puskesmas Bungin Kabupaten Lampung Barat. Tujuan 
penelitian untuk memperoleh gambaran karakteristik ibu hamil yang tidak melakukan kunjungan Keempat (K4) di Wilayah Kerja Puskesmas Bungin Lampung Barat.

\section{Metode}

Penelitian ini menggunakan metode penelitian deskriptif dengan pendekatan cross sectional. Rancangan ini digunakan untuk memperoleh gambaran karakteristik ibu hamil yang tidak melakukan kunjungan ulang pemeriksaan kehamilan keempat (K4) di Puskesmas Bungin Kabupaten Lampung Barat yang dilakukan bulan Juli 2015.

Populasi penelitian adalah semua ibu hamil yang tidak melakukan pemeriksaan kehamilan Keempat di Wilayah Kerja Puskesmas Bungin Lampung Barat yang berjumlah 246 orang. Sampel dalam penelitian adalah ibu hamil yang tidak melakukan kunjungan keempat (K4) pada masa kehamilan pada pada bulan Juni - Agustus 2015. Jumlah sampel penelitian dihitung dengan rumus Solvin dengan jumlah populasi atau $\mathrm{N}=246$ dan presisi $(\mathrm{d})=0,05$, sehingga diperoleh 152 sampel.

Varibel karakteristik responden yang diteliti dan dianalisis adalah variabel usia, pendidikan, pekerjaan, paritas dan jarak rumah tinggal ke fasilitas kesehatan yang tidak melakukan K4. Pengumpulan data dengan menggunakan data sekunder yang bersumber dari kohort ibu pada Puskesmas Bungin Lampung Barat menggunakan alat ukur kuesioner yang berisi sesuai variabel penelitian. Analisis data dengan analisis univariat dengan menghitung prosentase frekuensi masing-masing variabel penelitian.

\section{Hasil}

Hasil penelitian pada tabel 1 menunjukkan gambaran karakteristik ibu hamil menurut variabel usia, pendidikan, pekerjaan, paritas dan jarak rumah tinggal ke fasilitas kesehatan yang tidak melakukan kunjungan ulang pemeriksaan kehamilan keempat (K4). Tabel 1 memperlihatkan hasil dari 152 ibu hamil yang paling banyak yang tidak melakukan pemeriksaan kehamilan keempat (K4) adalah kelompok ibu hamil dengan usia risiko tinggi $(<20 />35)$ sebesar $91(60 \%)$. Ibu Hamil yang paling banyak yang tidak melakukan pemeriksaan kehamilan keempat (K4) adalah kelompok ibu hamil berpendidikan rendah sebesar 76 (50\%). Ibu hamil yang paling banyak yang tidak melakukan pemeriksaan kehamilan keempat (K4) adalah kelompok ibu hamil yang tidak bekerja sebesar 107 (70\%). Ibu hamil yang paling banyak yang tidak melakukan pemeriksaan kehamilan keempat (K4) adalah kelompok ibu hamil primipara dan multipara masing-masing sebesar 66 (43\%). Ibu hamil yang paling banyak yang tidak melakukan pemeriksaan kehamilan keempat (K4) berdasarkan jarak rumah tinggal ke fasilitas kesehatan adalah kelompok ibu hamil yang jarak rumah tingga ke fasilitas kesehatan jauh berjumlah $102(67,1 \%)$.

\section{Pembahasan}

\section{Karakteristik ibu hamil berdasarkan usia}

Usia adalah masa individu terhitung mulai saat dilahirkan sampai saat berulang tahun. Penelitian memperoleh hasil dari 152 responden di wilayah kerja Puskesmas Bungin dapat diketahui bahwa mayoritas ibu hamil yang tidak melakukan pemeriksaan kehamilan keempat adalah ibu hamil dengan usia berisiko tinggi sebanyak $60 \%$ orang. Kurun reproduksi sehat dikenal bahwa usia aman untuk kehamilan dan persalinan adalah 20-30 tahun. Kematian maternal pada wanita hamil dan melahirkan pada usia dibawah 20 tahun, 2-5 kali lebih tinggi dari pada kematian maternal yang terjadi pada usia 20-29 tahun dan risiko kematian meningkat kembali pada ibu hamil dan bersalin yang berusia 30-35 tahun. Pada usia rawan kemungkinan banyak kesulitan yang didapat ibu pada saat kehamilannya (Wiknjosastro, 2005). 
Tabel 1.

Distribusi Karakteristik Ibu Hamil yang Tidak Melakukan Pemeriksaan Ulang Kunjungan Kehamilan Keempat (K4)

\begin{tabular}{|c|c|c|c|}
\hline Variabel & Kategori & $n=152$ & $(\%)$ \\
\hline \multirow[t]{2}{*}{ Usia Ibu } & Risiko Tinggi $(<20 />35)$ & 91 & 60 \\
\hline & Tidak Berisiko (20-35) & 61 & 40 \\
\hline \multirow[t]{3}{*}{ Pendidikan } & Rendah (Tidak Sekolah/SD) & 76 & 50 \\
\hline & Menengah (SMP/SMA) & 67 & 44 \\
\hline & Tinggi (Perguruan Tinggi) & 9 & 6 \\
\hline \multirow[t]{2}{*}{ Pekerjaan } & Tidak Bekerja & 107 & 70 \\
\hline & Bekerja & 45 & 30 \\
\hline \multirow[t]{3}{*}{ Paritas } & Primipara & 66 & 43 \\
\hline & Multipara & 66 & 43 \\
\hline & Grandemultipara & 20 & 14 \\
\hline \multirow[t]{2}{*}{ Jarak ke fasilitas kesehatan } & Dakat & 102 & 67,1 \\
\hline & Jauh & 50 & 32,9 \\
\hline
\end{tabular}

Hasil penelitian ini sesuai dengan penelitian yang dilakukan (Heriati, 2008) yang menyatakan bahwa 16,7 \% kelompok ibu berisiko tinggi tidak memeriksakan kehamilannya, sedangkan penelitian yang dilakukan (Pangemanan, Nova, \& Juniver, 2014) menyatakan bahwa 20,8\% ibu hamil dalam kelompok usia berisiko tinggi yang tidak memeriksakan kehamilannya secara lengkap. Namun, penelitian ini tidak sejalan dengan penelitian (Sumiati, 2012) yang menyatakan bahwa ibu hamil yang tidak berisiko merupakan kelompok ibu hamil yang tidak teratur memeriksakan kehamilannya.

Semakin cukup usia, tingkat kematangan dan kekuatan seseorang akan lebih matang dalam berfikir dan bekerja. Usia ibu hamil merupakan salah satu faktor berisiko tinggi dalam kehamilan. Ibu dikatakan berisikotinggi, jika ibu hamil berusia dibawah 20 tahun atau usia diatas 35 tahun. Hal ini berkaitan dengan kesiapan alat reproduksi ibu untuk menerima keadaan hamil. Menghindari risiko tinggi kehamilan dan kesulitan persalinan pada usia risiko tinggi $(<20 />35$ tahun) maka ibu harus memeriksakan kehamilan secara teratur. Bidan sebagai tenaga kesehatan dapat memberikan informasi kepada ibu hamil tentang pentingnya pemeriksaan kehamilan secara teratur minimal sesuai standar yang telah ditetapkan pemerintah, yaitu $4 \mathrm{x}$ selama kehamilan yaitu $1 \mathrm{x}$ pada trimester 1 , 1x pada trimester 2 , 2x pada trimester 3 .

\section{Karakteristik ibu hamil berdasarkan pendidikan}

Hasil penelitian menunjukkan dari 152 ibu hamil terdapat mayoritas ibu hamil yang tidak melakukan pemeriksaan kehamilan keempat berpendidikan rendah sebanyak 76 (50\%) orang ibu hamil.Tingkat pendidikan sangat memengaruhi bagaimana seseorang untuk bertindak dan mencari penyebab serta solusi dalam hidupnya. Semakin tinggi pendidikan semakin baik pula tingkat pengetahuannya. Penelitian ini sejalan dengan penelitian (Kasim \& Raharjdjo, 2006) yang menyatakan bahwa $75 \%$ ibu hamil yang tidak melakukan pemeriksaan K4 berlatar belakang pendidikan rendah. Penelitian Sumiati (2008) juga menyatakan hal yang sama bahwa $91,7 \%$ ibu yang tidak lengkap melakukan pemeriksaan kehamilan adalah kelompok ibu hamil yang berpendidikan rendah (tidak tamat $\mathrm{SD})$.

Seorang wanita yang berpendidikan lebih terbuka terhadap ide-ide baru dan perubahan untuk mendapatkan pelayanan kesehatan karena manfaat pelayanan kesehatan akan mereka sadari sepenuhnya. Sedangkan, Ibu yang berpendidikan rendah ada kecenderungan mempunyai pengetahuan yang kurang tentang kesehatannya, ibu hamil yang berpendidikan rendah juga cenderung bersifat pasrah, menyerah pada keadaan tanpa ada dorongan untuk memperbaiki nasibnya. Hal ini dimungkinkan 
karena proses mendapatkan informasi tentang kesehatan ibu hamil hanya diperoleh melalui media penyuluhan namun masih dalam tahap pemahaman belum kearah penerapan. Diperlukan upaya penyampaian informasi tentang pentingnya pemeriksaan kehamilan khususnya pemeriksaan kehamilan keempat (K4) pada ibu hamil dengan menggunakan metode dan media yang disesuaikan dengan latarbelakang pendidikan ibu hamil.

\section{Karakteristik ibu hamil berdasarkan pekerjaan}

Hasil penelitian terhadap 152 responden di wilayah kerja Puskesmas Bungin menunjukkan bahwa mayoritas ibu hamil yang tidak melakukan pemeriksaan kehamilan keempat adalah ibu yang tidak bekerja (IRT) sebanyak 107 (70\%) orang ibu hamil.Pekerjaan seseorang menggambarkan aktivitas dan tingkat kesejahteraan ekonomi yang akan didapatkan. Tingkat sosial ekonomi terbukti sangat berpengaruh terhadap kondisi kesehatan fisik dan psikologis ibu hamil. Ibu yang bekerja mempunyai tingkat pengetahuan yang lebih baik daripada ibu yang tidak bekerja, karena pada ibu yang bekerja akan lebih banyak memmiliki kesempatan untuk berinteraksi dengan orang lain sehingga lebih mempunyai banyak peluang juga untuk mendapatkan informasi seputar keadaannya (Sulistyowati, 2009)

Penelitian ini sejalan dengan hasil penelitian yang dilakukan oleh (Sjofiatun, 2000) yang menyebutkan bahwa status ibu bekerja mempunyai pengaruh yang signifikan terhadap perawatan kehamilan termasuk dalam pemeriksaan kehamilan. Penelitian ini tidak sesuai dengan hasil penelitian Gabriellyn S.P, et al (2013) yang menyatakan bahwa ibu hamil yang bekerja yang melakukan kunjungan antenatal lebih teratur. Perempuan yang bekerja lebih memanfaatkan pelayanan antenatal care dibanding ibu rumah tangga dan ibu yang tidak bekerja (Kabir; et. al, 2005). Pekerjaan bukanlah penghambat dalam bertindak, bila ada kemauan ataupun ibu memiliki pengetahuan yang baik terhadap kesehatan, maka ibu akan berusaha untuk melakukan tindakan dalam hal ini memeriksakan kehamilan (Rohan \& H, 2013).

\section{Karakteristik ibu hamil berdasarkan paritas}

Hasil penelitian yang dilakukan terhadap 152 responden Primipara atau multipara masing-masing sebanyak 66 (43\%) orang ibu hamil. di Wilayah Kerja Puskesmas Bungin yang tidak melakukan pemeriksaan kehamilan keempat adalah primipara dan multipara. Ibu yang pertama kali hamil merupakan hal yang baru, sehingga termotivasi dalam memeriksakan kehamilannya. Sebaliknya ibu yang sudah pernah melahirkan lebih dari satu orang mempunyai anggapan bahwa ia sudah berpengalaman sehingga tidak termotivasi untuk memeriksakan kehamilannya.Ibu yang pernah melahirkan mempunyai pengalaman tentang pemeriksaan kehamilan, sehingga dari pengalaman yang terdahulu kembali dilakukan untuk menjaga kesehatan kehamilannya.

Paritas secara statistik memiliki efek negatif yang signifikan terhadap kehadiran dalam pemanfaatan pelayanan antenatal. Paritas ke 2-3 merupakan paritas paling aman ditinjau dari sudut kematian maternal. Paritas 1 dan paritas lebih dari 3 (paritas tinggi) mempunyai angka kematian maternal lebih tinggi. Lebih tinggi paritas, lebih tinggi kematian maternal (Wiknjosastro, 2005). Risiko pada paritas 1 dapat ditangani dengan asuhan obstetri lebih baik, sedangkan pada paritas tinggi dapat dikurangi atau dicegah dengan keluarga berencana (Wiknjosastro, 2005) karena sebagian kehamilan dengan paritas tinggi adalah tidak direncanakan. Hal ini ada kecenderungan dimana ibu merasa tidak siap sehingga tidak respon untuk memeriksakan kehamilan. Diperlukan upaya tenaga kesehatan khususnya bidan dalam pemberian informsi melalui penyuluhan kepada ibu hamil tentang pentingnya pengaturan kelahiran serta kesiapan kehamilan berikutnya. 


\section{Karakteristik ibu hamil berdasarkan jarak rumah tinggal dengan fasilitas kesehatan}

Hasil penelitian berdasarkan 152 responden, ibu hamil yang paling banyak yang tidak melakukan pemeriksaan kehamilan keempat (K4) berdasarkan jarak rumah tinggal ke fasilitas kesehatan adalah kelompok ibu hamil yang jarak rumah tingga ke fasilitas kesehatannya dekat sebesar 102 $(67,1 \%)$. Hasil penelitian ini menjelaskan bahwa sebagian besar ibu hamil yang tidak melakukan pemeriksaan K4 mrmpunyai jarak rumah tinggal ke fasilitas kesehatan yang dekat. Hal ini sesuai dengan penelitian (Arwiani, 2013) dengan hasil bahwa 81,8\% ibu hamil yang tidak melakukan pemeriksaan K4 jarak rumah tinggalnya ke fasilitas kesehatan dekat. Namun, penelitian ini tidak sesuai dengan hasil penelitian Tsegay Yalem yang menyatakan bahwa jarak mempengaruhi pemanfaatan pelayanan antenatal yaitu jarak fasilitas yang jauh menyebabkan ibu hamil tidak berkunjung ke sarana kesehatan untuk melakukan pelayanan antenatal. Teori health service use dari Andersen yang menjelaskan bahwa salah satu faktor yang mempengaruhi perilaku pemanfaatan pelayanan kesehatan adalah kebutuhan yang dirasakan (perceived need). Seseorang yang merasa sakit akan memanfaatkan pelayanan kesehatan dan sebaliknya, seseorang yang sebenarnya membutuhkan pelayanan kesehatan tetapi merasa sehat akan memanfaatkan pelayanan kesehatan.

Hasil penelitian ini menunjukan kecenderungan bahwa jarak bukan menjadi prediktor terhadap aksesbilitas pada pelayanan kesehatan, artinya jarak rumah tinggal ke fasilitas kesehatan tidak mempengaruhi ibu hamil untuk melakukan pemeriksaan K4. Prilaku ibu hamil kemungkinan tidak melakukan K4 selain karena faktor jarak, yaitu kebutuhan yang dirasakan terhadap pentingnya pemeriksaan kehamilan. Meskipun, tersedia tempat pelayanan dengan jarak yang dekat, ibu hamil tidak memanfaakan pelayanan kesehatan terdekat untuk menjaga kesehatan kandungan kehamilannya.

\section{Simpulan dan saran}

Simpulan penelitian memperoleh gambaran karakteristik ibu hamil yang tidak melakukan kunjungan ulang pemeriksaan kehamilan keempat (K4) paling banyak berusia risiko tinggi (67\%), berpendidikan rendah berjumlah $50 \%$, tidak bekerja $70 \%$, paritas berisiko (primipara dan multipara) $43 \%$ dan ibu hamil yang jarak rumah tinggal ke fasilitas kesehatannya dekat terdapat $67,1 \%$. Pencapaian cakupan $\mathrm{K} 4$ perlu ditingkatkan dengan upaya meningkatkan pelayanan dan melakukan promosi kesehatan dengan memperhatikan karakteristik ibu hamil, tentang pentingnya dan manfaat dari pemeriksaan kehamilan yang dilakukan secara teratur, minimal sesuai standar yang telah ditetapkan yaitu 4 kali selama kehamilan.

\section{Referensi}

Arwiani, T. (2013). Faktor-faktor yang mempengaruhi pemanfaatan pelayanan antenatal di Puskesmas kota Bandung tahun 2013. Retrieved from http//pustaka.unpad.ac.id/wp-content/

Departemen Kesehatan RI. (2008). Panduan pelayanan antenatal. Jakarta: Depkes RI.

Depkes RI. (2004). Kebijakan dasar pusat kesehatan masyarakat tahun 2004. Jakarta: Depkes RI.

Depkes RI. (2006). Pelayanan kesehatan neonatal esensial. Depkes RI: Depkes RI.

Depkes RI. (1993). Peningkatan peran serta masyarakat dalam gerakan sayang ibu panduan bagi petugas kebupaten. Jakarta: Depkes RI.

Dinkes Kabupaten Lampung Barat. (2013). Profil Kesehatan Kabupaten Lampung Barat. Krui: Dinkes Lampung Barat.

Gabriela, A. L. (2014). Hubungan antara pengetahuan, status pendidikan, dan status pekerjaan ibu dengan kunjungan antenatal care di Puskesmas Teling Atas Kecamatan Wanea Kota Manado 
Fakultas Kesehatan Masyarakat Universitas Sam Ratulangi Manado. Retrieved from (http://fkm.unsrat.ac.id) [01 Januari 2017].

Heriati. (2008). Faktor-faktor yang mempengaruhi rendahnya cakupan kunjungan ulang pemeriksaan kehamilan K4 di Puskesmas Sei Nyamuk Tahun 2008. Tesis. Surabaya: Program Pascasarjana Universitas Airlangga.

Kabir, et. al. (2005). Determinant of Utilization of Antenatal Care Service in Kumbotso Village. Northern Nigeria: Tropical Doctor.

Kartono, K. (2008). Patologisosial. Jakarta: PT Raja GrafindoPersada.

Kasim, F., \& Raharjdjo, T. M. (2006). Faktor-faktor yang mempengaruhi rendahnya cakupan K4 di desa Sukarame kecamatan Sukanagara Kabupaten Cianjur tahun 2005-2006. Jurnal Kesehatan, 6 (2).

Kemenkes RI. (2013). Riset kesehatan dasar. Jakarta: Badan penelitian dan pegembangan Kesehatan Kementrian Kesehatan RI.

Notoatmodjo, S. (2005). Promosi kesehatan teori dan aplikasi. Jakarta: Rineka Cipta.

Overbosch, G., Nsowah, N. N., \& den, B. G. (2004). Determinant of antenatal Care Use In Ghana. Journal of African Economies .

Pangemanan, J. M., Nova, H., \& Juniver, H. L. (2014). Hubungan antara karakteristik ibu hamil dengan pemanfaatan pelayanan K1 dan K4 di Puskesmas Motoling Kabupaten Minahasa Selatan Tahun 2014. Bidang Minat Administrasi dan Kebijakan Kesehatan.

Pusdiknakes-WHO-JHPIEGO. (2003). Asuhan antenatal (Vol. 2). Pusdiknakes -WHO-JHPIE.

Rocha, M. M. (2012). Faktor yang berhubungan dengan keteraturan kunjungan antenatal di wilayah kerja Puskesmas Sudiang Raya Makassar Tahun 2011. Skripsi. Makasar: FKM Universitas Hasanuddin Makassar.

Rohan, H., \& H, S. (2013). Buku ajar kesehatan reproduksi. Yogyakarta: Nuha Medika.

Simkhada, B., Van, T. E., \& Porter, P. (2008). Factors affecting the utilization of antenatal care in developing countries: systematic review of the literature.

Sjofiatun, N. (2000). Pengaruh karakteristik wanita dan rumah tangga terhadap pemanfaatan pelayanan kesehatan ibu di Indonesia (analisis data SDKI 1997). Jakarta: Universitas Indonesia.

Sulistyowati, A. (2009). Asuhan kebidanan pada masa kehamilan. Jakarta: Salemba Medika.

Sumiati. (2012). Faktor-faktor yang berhubungan dengan kunjungan pemeriksaan kehamilan k4 di puskesmas dengan tempat perawatan Sindang Ratu kabupaten Garut tahun 2012. Jakarta: FKM Universitas Indonesia.

Surachman, A. (2008). Determinan unmetneed persalinan di Kabupaten Garut Tahun 2008. Jakarta: FKM Universitas Indonesia.

Wiknjosastro, H. (2005). Ilmu kebidanan (3 ed.). Jakarta: Yayasan Bina Pustaka Sarwono Prawirohardjo. 